\title{
Korea's accelerating stem-cell work prompts calls for global ethical rules
}

A landmark paper in stem-cell research has
been seized on by both sides of the cloning
debate, as they seek to further their respective
causes. But the advance has also led ethicists
to call for broader international agreement
over how such studies should be conducted.

On 19 May, a team led by Woo Suk Hwang of Seoul National University in South Korea reported that it had created 11 human embryonic stem-cell lines that are genetically matched to individual patients (W.S. Hwang et al. Science doi:10.1126/ science.1112286; 2005).

Hwang's team is the first to report this achievement, and the work has been hailed by scientists as a major breakthrough, because it could allow researchers to follow the development of a patient's disease in a Petri dish, instead of in animal models. Eventually, the work could lead to therapies, but scientists caution that this could be years away - and might never happen.

"This is a huge advance that could help us get at a lot of diseases that remain mysterious," says George Daley, a stem-cell researcher at Harvard Medical School in Boston, Massachusetts. "I wish we were doing this work here."

But even as scientists lauded Hwang's work, others condemned it because of the technique he used to create the cell lines. The procedure, often described as 'therapeutic cloning, involves taking a skin cell from a patient and extracting its nudeus. This is then placed inside a donated human egg stripped of its own genetic material, and the egg is allowed to begin developing into an embryo. After a few days, when it has reached the stage known as a blastocyst, scientists can extract stem cells that are an exact genetic match to the patient. But critics say that creating a blastocyst and then destroying it is equivalent to creating and destroying a human life.

One of these critics is US President George Bush, who says that Hwang's research is morally troubling. "I'm very concerned about doning, ${ }^{n}$ Bush told reporters on 20 May. "I worry about a world in which cloning becomes acceptable."

Bush's concern perhaps reflects the fact that US lawmakers are preparing for their first vote on a proposal to loosen rules on stem-cell research that he set on 9 August 2001. These rules prevent federal funds

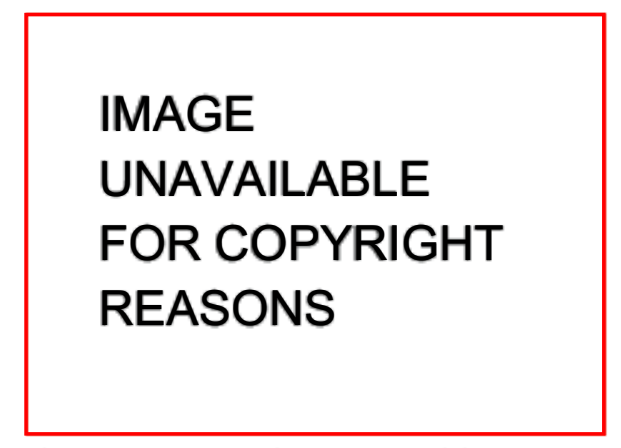

Clone ranger: Woo Suk Hwang is widely seen as being at the frontier of stem-cell research.

from being used for work on human embryonic stem-cell lines derived after that date. But revelations about weaknesses of available cell lines - and opinion polls suggesting that supporters of Bush's party may not back his policy - brought the issue to a head in the run-up to this week's vote.

Others are using Hwang's results to argue that the field should speed up outside Korea. Speaking at the Science Museum in London on 20 May, Nobel laureate James Watson lambasted Britain's "piss-poor" approach to stem-cell research. He described some UK cloning work as "nice science", but said lack of funds meant it wasn't moving fast enough. "You want to bein the sameleague as the Koreans, but you are a bit player," he said.

But an accelerating field would increase demand for donated eggs, which raises its own ethical problems. An international effort to coordinate stem-cell research would lend transparency to the field and ensure it proceeds in an ethical way, says Arthur Caplan, a bioethicist at the University of Pennsylvania.

South Korean Sang-yong Song, who is president of the Asian Bioethics Association, agrees. He worries that Hwang's paper will be used by some countries as an excuse to accelerate research, before consensus about how to do the work is reached. "Even in Korea there is no national consensus on promoting biotechnology", he says.

"There is a real need for international control," Caplan says. "Nations are moving," he adds, noting that people against stem-cell work shouldn't "simply stand on the sidelines pouting and saying 'you can't do this'." Erika Check

Additional reporting by David Cyranoski 